\title{
Teachers' Perceptions in Implementing Technologies in Language Teaching and Learning
}

\author{
Caroline V. Katemba \\ linakatemba@gmail.com \\ Universitas Advent Indonesia, Bandung- Indonesia
}

\begin{abstract}
Technologies have swept the world in every aspect of life including the education system. And therefore, the purpose of this research is to find the Challenges Encountered in implementing technologies in Language Teaching and Learning in Indonesia. This study was a quantitative method in nature. The participants of the study were randomly chosen 30 teachers from Bandung in the rural area. The data were collected by using questionnaires and were analyzed by using mix method that is quantitative and qualitative procedures.

The result showed that using technology in the classroom was helpful. In addition to that, more tools and facilities provided by schools are increasingly helping them improve their ability to use technology. Though the school has prepared facilities there were several challenges found in the implementation of technologies in the Language Learning classrooms. Additional results of this study give meaningful insights for policymakers about the implementation of ICT for teaching and learning in the classroom.
\end{abstract}

Keywords: Teacher's beliefs and perception, Challenges in Technology, educational technology

\section{INTRODUCTION}

Teaching English using technology is not a new concept or practice for teachers around the world, especially when English is taught in non-native speaking countries. There are two effective ways to improve students' language skills; staying abroad and using multimedia (Muslem \& Abbas, 2017). The last two decades witnessed a worldwide proliferation of information and communication technologies (ICT), henceforth it penetrates into the field of education. The global adoption of ICT into education has often been premised on the potential of the new technological tools to revolutionize an out modeled educational system, better prepare students for the information age, and/or accelerate national development efforts. In developing countries, in particular, the above promises have generated a whole set of wild speculations about the necessity of educational reforms that will accommodate the new tools (Pelgrum, 2001). Governments in most developing countries have responded to the challenge by initiating national programs to introduce computers into education.

One developing country that is currently pursuing the technological track in education is Indonesia included Bandung. Bandung is in the west of Java island and is known as a student city, its students come from several cities across the nation and there are many prestigious schools and universities in Bandung. Therefore, every school competes healthily and one of the criteria people are looking for it has complete facilities including technological facilities following the progress of the era. In fact, increasing numbers of teachers are using computers and the internet in their classrooms (katemba 2019). in addition to facilities, schools also demand teachers who are not outdated in the sense of being able to follow and use technology fluently, especially in the classroom at the time of teaching. However, as time goes by, there are still some teachers who have not been able to use technology in the classroom while teaching or do not need technology. In the context of 
technology use in the classroom, studies have also shown that teacher beliefs and attitudes influence teachers' use of computers in the classroom (Ertmer \& Hruskocy, 1999; Marcinkiewicz, 1994; Tearle, 2004; Katemba 2019), and there is a relationship between teachers' beliefs and their instructional decisions (Haney, Czerniak, \& Lumpe, 1996; Mumtaz, 2000). For example, teachers are more likely to adopt new technology if they can use it following their existing beliefs and practices (Veen, 1993). Many teachers encountered the problem of perception when using ICT in the teaching and learning process in the classroom (Kurniawan, 2014). Various studies have acknowledged that although teachers appear to recognize the value of ICT in education, difficulties nevertheless continue to be encountered during the process of technology/ ICT integration (Balanskat, et al. 2006;

Silviyanti and Yusuf, 2015)

Furthermore, few studies have examined these effects in the longitudinal context of a technology-enhanced learning environment. The present study seeks to fill this gap. Particularly, it seeks to learn: 1. What are the perceptions of English teachers in public high schools in Bandung on the use of ICT in English language teaching?

2. What are the challenges encountered in the use of ICT in English language teaching?

\section{Literature Review}

Teaching English using technology is a method that is in demand especially during this era of lockdown due to COVID-19 where everybody is using online in teaching. Rank, Warren, and Millum, (2011) said in his study cited by Muslim et al. that "Teaching English using technology is not a new concept or practice for teachers around the world". Wadmany (2006) entitled "Teachers' Beliefs and Practices in Technology-based Classrooms: A Developmental View". The result of this study finds out that following multi-year experiences in technologybased classrooms, teachers' educational beliefs had changed quite substantively, demonstrating multiple views rather than pure beliefs. The study argues that teachers' beliefs form a mosaic of complementary visions, even conflicting ones. It also shows that it is easier to change classroom practices than educational beliefs. Which is in this study, the researcher selected 6 teachers, initially, four were chosen from the fourth and fifth grades, and two more teachers were added in the second year.

In a study done by Albirini (2004) entitled "Teachers attitudes toward information and communication technologies: the case of Syrian EFL teachers" reveal the result that the findings suggest that teachers have positive attitudes toward ICT in education. Teachers' attitudes were predicted by computer attributes, cultural perceptions, and computer competence. The results point to the importance of teachers' vision of technology itself, their experiences with it, and the cultural conditions that surround its introduction into schools in shaping their attitudes toward technology and its subsequent diffusion in their educational practice. The researcher used the methodology of a descriptive study of an exploratory nature. The teachers were selected randomly 887 (214 males, 24\%; 673 females, 76\%).

Meanwhile, in a study done by Nikian, et al (2013) entitled "Malaysian Teachers' Perception of Applying Technology in the Classroom" said that the findings indicate that although Malaysian English teachers were using technology and have positive perceptions towards using technology in the classroom, they feel they must undergo training in this aspect. They view time constraints and access to equipment as the main obstacles to implementing technology in the classroom. This research concludes that although Malaysian teachers are faced with some difficulties in implementing technology in the classroom, they see a value in 
technology and want to use technology in the classroom. The research was done by using quantitative survey methods and using questionnaires.

\section{METHODOLOGY}

The design of this study uses a mixed method of quantitative and qualitative research design. This study involves 30 English teachers in Bandung which were chosen randomly from different schools to represent the study. Ten teachers were selected randomly to join the focus group discussion (FGD) or interview to get their perception and challenges based on their experiences on using this technology in their classroom. They join the FGD voluntarily after they have answered the written questions.

The 30 teachers consist of, 7 teachers aged 31-35 years, 10 teachers aged 36-40 years, 9 teachers aged 41-45 years, 4 teachers aged 46-50 years. In terms of gender, there were 9 male teachers and 21 female teachers. In degree, they were mostly Bachelor's degrees. In terms of teaching experience, there were 10 teachers with 7-10 years of teaching experience, 13 teachers with 11-15 years, 3 teachers with 16-20 years, and 4 teachers with 21 years of experience and above. The teachers were assured that the information they gave was confidential and used strictly for research and academic purposes only.

In this study, the researcher used quantitative \& qualitative mixed-method research by using questionnaires analysis. The research questions were designed to see the teachers' perceptions and challenges of the implementation of ICT in English language teaching classrooms. The questionnaire was designed and modified from Muslem, Yusuf, Juliana, (2018) for the mixed-method approach (qualitative and quantitative research). All section and basic information are modified from Muslem, et.al. (2018) including the 20 questionnaires are provided. It focused on English teachers' perceptions and challenges of the implementation of ICT in their teaching. The questionnaire was formatted by using the Likert Scale of (1) strongly disagree (SD), (2) disagree (D), (3) neutral (N), (4) agree (A), and (5) strongly agree (SA). The questionnaire is available in the Appendix. The instrument was given to 30 English teachers in Bandung, Indonesia. They were given 35 minutes to answer all the questions in the questionnaire completely in front of the researchers. The data from questionnaires were analyzed quantitatively using Microsoft Excel 2010 for the frequency and percentages of each item.

\section{FINDINGS \& DISCUSSION}

The results of the questionnaire: English teachers' perceptions and challenges encountered in implementing the technologies/ICT.

There are twelve items out of 20 in the questionnaire focused on English teachers' perceptions of the implementation of technologies in English language teaching (ELT) classrooms.

The questionnaire was formatted by using the Likert Scale of (1) strongly disagree (SD), (2) disagree (D), (3) neutral (N), (4) agree (A), and (5) strongly agree (SA). The questionnaire is available in the Appendix. The pie charts display the results. Figure 1-6 showed the positive responses of the teachers toward the questionnaire, on the other hand, figure 8-12 showed that they strongly disagree and disagree with the statement in the questionnaire. Though their responses geared to give an answer to the English teachers' perception upon implementing technologies/ICT in the English Language Teaching classrooms. 
English teachers' perception upon implementing technologies/ICT in the English Language Teaching classrooms.

Figures 1-6. English teachers' perceptions on the use of technologies

(Responses on agreeing \& strongly agree to the statements)

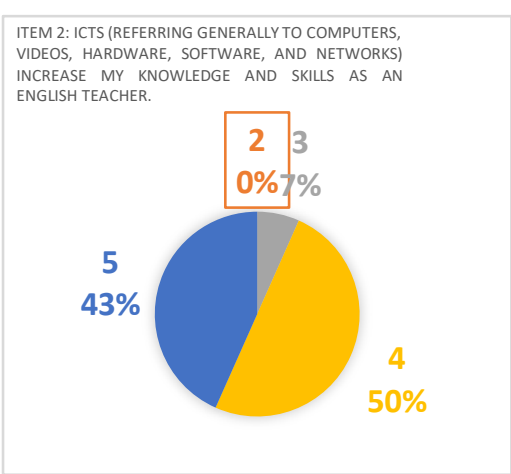

Fig.1

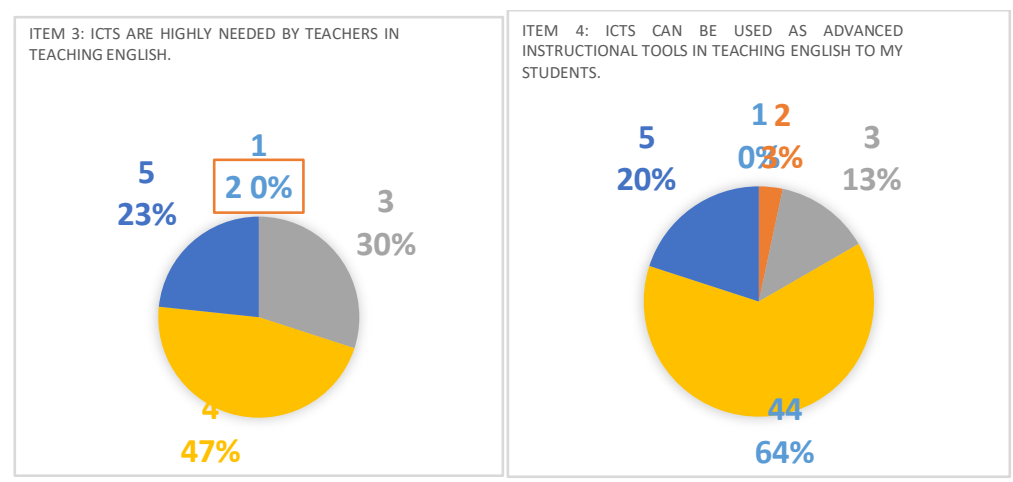

Fig.2

Fig.3

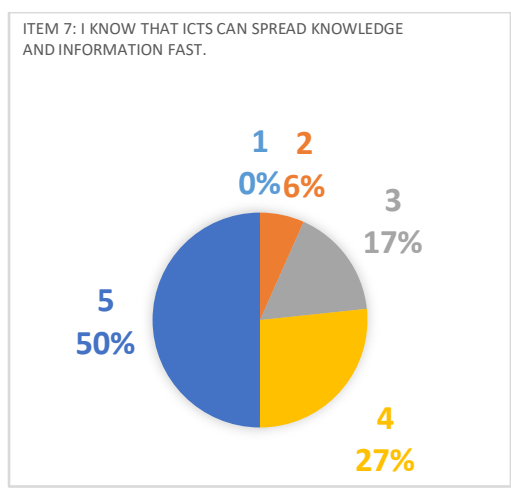

Fig.4

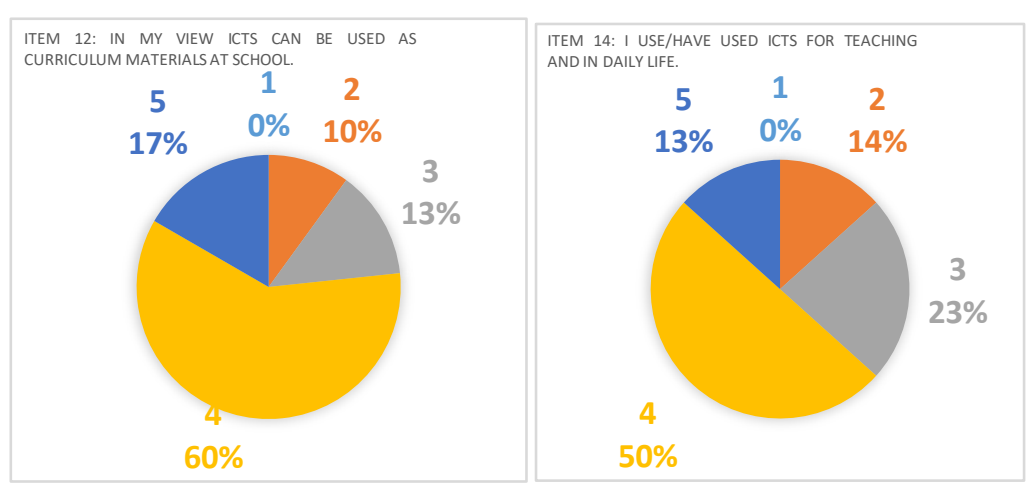

Fig. 5

Fig.6

Figures 1-6 showed that about 93\% agree that technologies/ICTs increase teachers' knowledge and skills as English teachers, about $70 \%$ agree that technologies/ICT is highly needed by teachers in teaching English, about 84\% agree that technologies/ICT can be used as advanced instructional tools in teaching English to students, and about $77 \%$ of the respondents agree that technologies/ICT can spread knowledge and information fast, about $77 \%$ of the teachers agree that technologies/ICT can be used as curriculum material at school. Meanwhile, there are about $63 \%$ of teachers have used ICT in their teaching and daily life, and to support the implementation of technologies/ ICT corroborate that claim some excerpts from the teachers are put in the following taken from the interview of what happened in the field (E refers to Excerpt from the interview and T refers to Teacher): 
E1, T (1): I agree that technologies/ ICTs (referring generally to computers, videos, hardware, software, and networks) increase my knowledge and skills as an English teacher. I can learn through technologies/ICT how other English teachers across the nation and across the globe deliver their lesson in the ELT classroom differently and so I tried it in my class and it was so exciting for my students. I have never thought that 'Kahoots games' could be used in teaching English in the ELT classroom. I also learn about giving tests paperless through Proprofs and also now I am using Edmodo and many more which I learned all through ICT. And most of all I saw that my students enjoyed, excited and were motivated to learn the lesson.

Rusanganwa, J. (2013) in his study found that the integration of technologies/ICT in education can facilitate teaching and learning with the use of CALL and showed better vocabulary recall. Similarly, Alavinia, P., Qoitassi, K. (2013) found that Text messaging tools, like cell phones, help foster the development of practice and learning words and also motivate them to do more writing. Tengku, M., S. \& Yusus, Y., Q. (2015) in their study pointed out that teachers who were using technology in teaching language have positive perceptions towards students' motivation and make learning enjoyable, interesting, and effective. Similarly, another excerpt was taken due to $84 \%$ agree that technologies/ICT can be used as advanced instructional tools in teaching English to students.

E2, T(8): I do agree that technologies/ICT can be used as advanced instructional tools in teaching English to students because when my students browse on a topic that I gave them, they can find something new that is not in the text that we are discussing in the class but rather they found that from the internet while browsing. For example, we were discussing the kind of (oranges) and one of my students said, teacher, I found a new variety of Jeruk (orange) which is called Jerpa- it means Jeruk papaya. It's a combination of orange and papaya so it is called Jerpa. The skin is thick like papaya but the covering of the skin is just like orange, the most inner part is like orange/lemon. From there I do learn something new and due to ICT is used as advanced instructional tools in teaching English to my students.

E3, T(9): I do agree that technologies/ICT can be used as advanced instructional tools in teaching English to my students because from my experienced, once I asked them to make a conversation on "greetings- how do you greet people" and at that time I was not able to give them samples of greetings because my principal called me because we were having school accreditation at that time. So, I asked my students to browse YouTube while I was away, and, to my surprise, most of my students can perform very well with perfect pronunciation and accent because they watched that on YouTube and perform that in class.

According to Chow (2015) and Gorra and Bhati (2016), most students are likely to use technology in the classroom for positive consequences in enhancing learning-related activities in the classroom. And so, the use of technology in the class really helps the students and the teacher to achieve their goals together easier. Moreover, Marie- Anne, Kupczynski, L., Kee, R.(2013) pointed out the increase in the use of technology in the classrooms has resulted in growth in student engagement, excitement, acceleration of learning, and proficiency. 
Figures 7-10. English teachers' perceptions on the use of technologies (Responses on disagreeing \& strongly disagree to the statements)

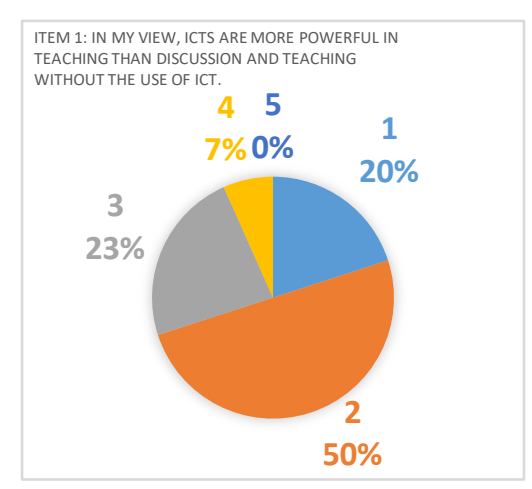

Fig.7

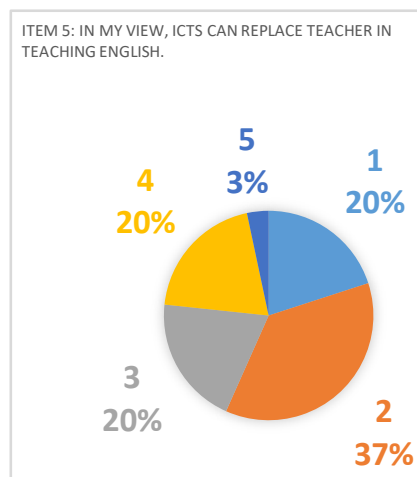

Fig. 8

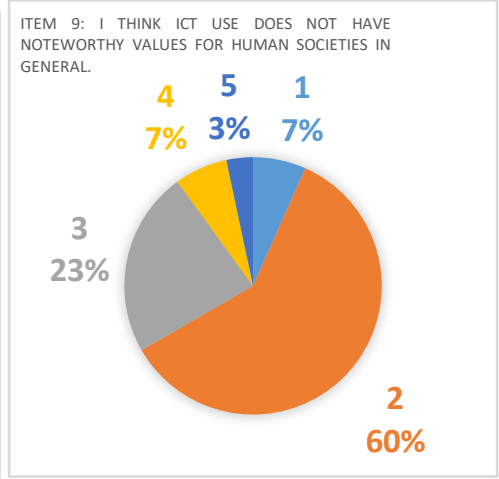

Fig.9

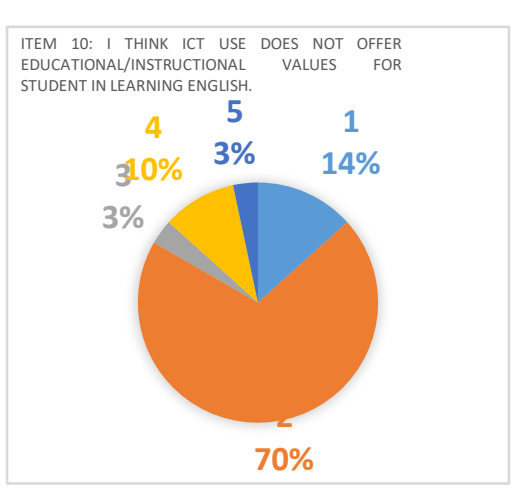

Fig. 10

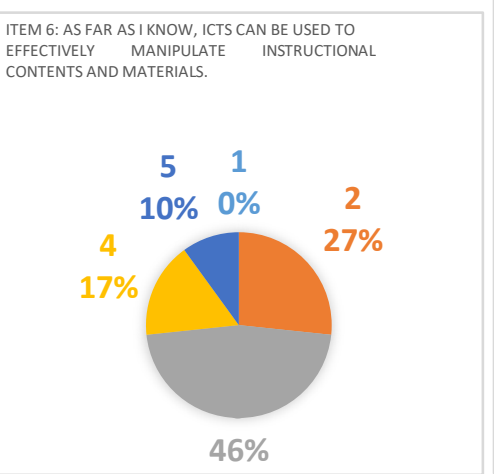

Fig.11

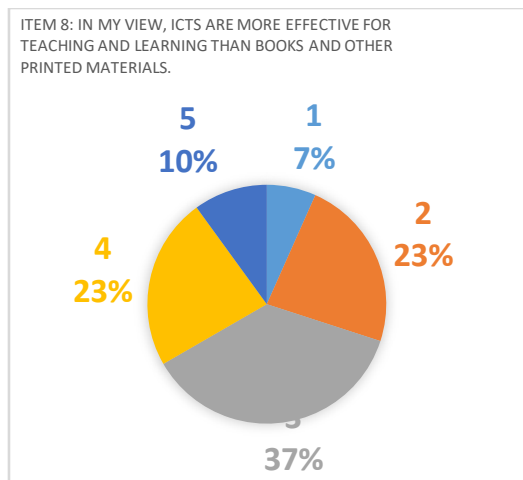

Fig.12

In figure 7 , the responses from the 30 teachers showed that roughly $70 \%$ of the teachers disagree that technologies/ICTs are more powerful tools of teaching than discussion and teaching without the use of ICT, roughly $67 \%$ disagree that technology has noteworthy values for human societies in general, roughly $84 \%$ of the teachers disagree to the statement "I think technologies/ICT use does not offer educational/instructional values for the student in learning English. So, it means to say that they in favor that technologies/ ICTs offer educational values for students in learning English. And it showed that the teachers have a positive attitude towards the use of technology/ICT. Further, technology is an important aspect of successful teaching. The results showed that teachers had a positive attitude towards technology, especially computers (Mollaei \& Riasati, 2013).

In figure $11 \& 12$ showed that nearly $37 \%$ neutral that ICTs are more effective for teaching and learning than books and other printed materials, and nearly $47 \%$ neutral that ICT can be used to effectively manipulate instructional contents and materials. Nonetheless, $57 \%$ of teachers disagree that ICT can replace the teacher in teaching English. It is principally concluded that teachers do believe that technologies/ICT supports their teaching and learning processes in the ELT classrooms but cannot replace the teacher. Some excerpts from the teachers that support the implementation of technologies/ ICT in teaching corroborate that claim as follow (E refers to Excerpt from the interview and $\mathrm{T}$ refers to Teacher): 
E4 (T5): I agree that technologies/ICT are powerful tools of teaching. Compared to printed books, technologies/ICT are more interesting, why? It is because the students will not feel bored when learning English. For example, the information that we give through technologies/ICT is colorful, alive, or animated and students can find many related pictures or topics to fascinates their understanding of the lesson, besides that, the students can directly watch conversation videos. ICT makes teaching more interesting and time-efficient because as a teacher I can get supported or back up materials for my lesson and that makes teaching easier. If we do discussions using ICT, the information that we get is more varied. It makes discussion alive, motivating, and easier.

As evidenced in E4, T5 agreed that ICTs are powerful tools in teaching and this is as what Gonne (2018) in his study, the results indicate that the teachers believe that using technology in teaching is inevitable, they like and want to learn more. A similar study by Granito and Chernobilsky (2012) stated with ICT, students can watch videos that are closer to real life presentation compared to printed books. Furthermore, most teachers believe that technologies/ICT has noteworthy values for human societies in general. An example is the fast spread of important information for the society, as provided by T10 on the following excerpt.

E5, T (10): Yes, through technology/ICT I can get important information for the society, for example, when we had the tsunami in Palu we were able to get that very important information very fast through ICT. I was able to call my family in Palu though I am in Java island updated of information is fast with the use of ICT.

\section{English teachers' challenges in using technologies/ICT}

Figure 13- 20 shows the findings from the questionnaire the teachers completed on the challenges they face while implementing technology in the classroom.

Figure 13-20 English teachers' challenges in implementing technologies/ICT

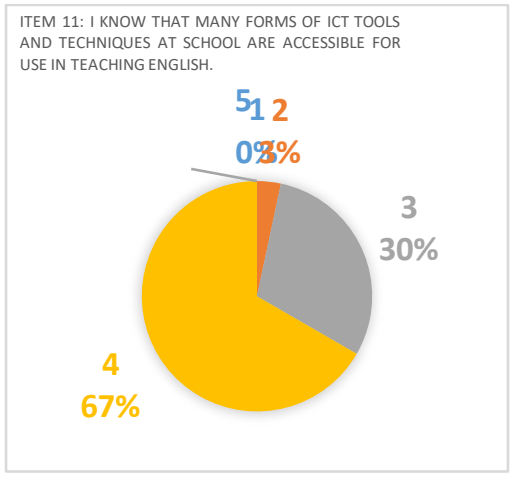

Fig.13

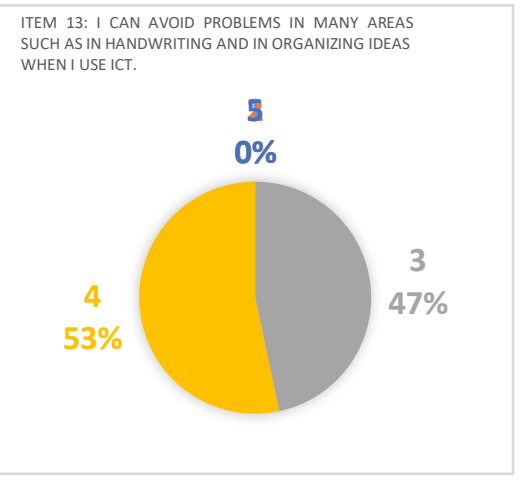

Fig.14

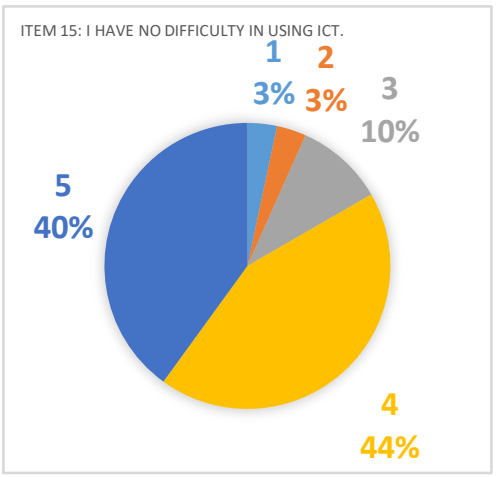

Fig.15 


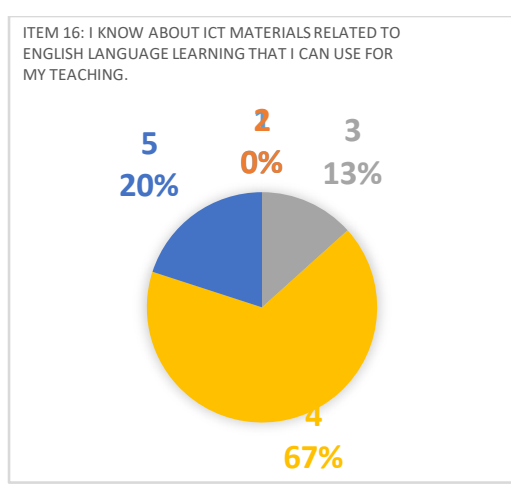

Fig.16

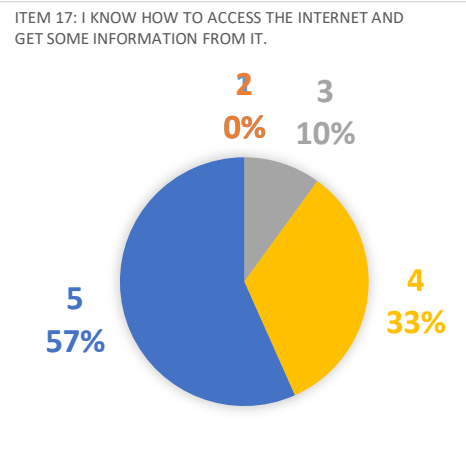

Fig. 17

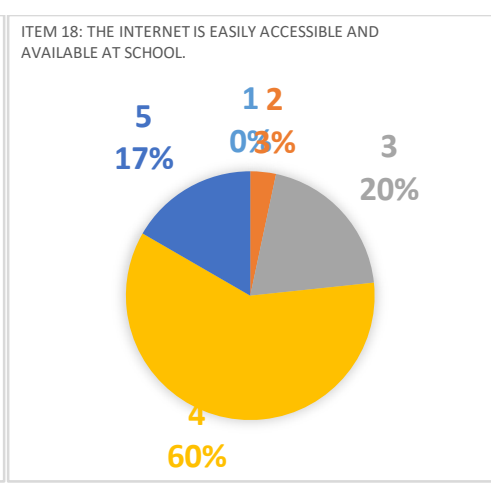

Fig.18

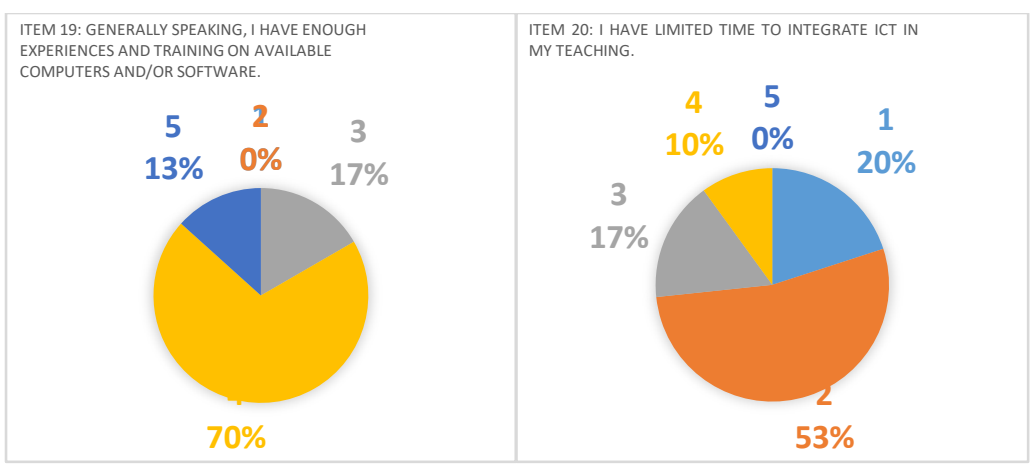

Fig.19

Fig.20

Figure 13-20, proves that most teachers know how to access the Internet and get some information from it, about $67 \%$ of the teachers agree that many forms of technologies/ICT tools and techniques in their school are accessible for use in teaching English, roughly 53\% agree that they can avoid problems in many areas such as in handwriting and in organizing ideas when they use ICT, and roughly $83 \%$ agree that they have no difficulty in using ICT. Nearly $87 \%$ know about ICT materials related to English language learning that can be used for their teaching. Likewise, $90 \%$ of the teachers know how to access the internet and get some information from it. Similarly, about $77 \%$ agree that the Internet is easily accessible and available at their school. However, $83 \%$ have enough experience and training in using available computers and/or software, and nearly $73 \%$ have limited time to integrate ICT in their teaching. Hence, it can be concluded that most public schools in Bandung provide many forms of ICT tools and techniques accessible for use in teaching English and most teachers know how to use ICT tools. Even so, problems exposed by the teachers on its accessibility in schools, and these become the challenges in implementing technology/ ICT are as follows:

1. Lack of teacher's confidence

Excerpt taken from Teacher 3 stated:

E6, T (3): I am not confident when using ICT/ technology in the classroom because I am not expert, lack of skills in using it.

E7, T(2): I am not confident to use technology because my students are better than I am. 
E8, T(9): I use the computer for personal purposes only-browsing.

2. Lack of teacher's qualification.

Key among all challenges is the lack of adequate, ongoing professional development for teachers who are required to integrate new technologies into their classrooms yet who are unprepared or unable to understand new technologies. About 8 teachers said that they did not have enough experience and training in the use of technology/ICT in the classroom. T5, who lacks experience in using ICT, bluntly explained:

E9, T(5): The tools are accessible in my school. The internet is also connected, but the problem is that I cannot use it. I do not know how to use any of the tools. So, I decided to not use it for my teaching.

All too often, when schools mandate the use of a specific technology, teachers are left without the tools (and often skills) to effectively integrate the results are that the new investments are underutilized, not used at all, or used in a way that mimics an old process rather than innovating new processes that may be more engaging for students.

3. Resistance to change

Resistance to technology comes in many forms, but one of the key resistance challenges identified in the report is "comfort with the status quo. According to the research, teachers and school leaders often see technological experimentation as outside the scope of their job descriptions.

E10, T(6): Anyways, I am comfortable with teaching traditionally without the use of technology/ICT

4. Negative attitude

This negative attitude is also one of the factors that hinder technology integration in the classroom for the teachers (Binginlas, 2009)

E11, T(7): I do not know how to use any of the tools. I decided to not use it for $m$ y teaching. I know a teacher who can use ICT but rarely uses it teaching, because like I said, a lot of paperwork to do. So, he came to class and teach by the textbooks; no time to search for new materials from

the internet and prepare them for teaching. Anyways, I am teaching traditionally without the use of ICT.

\section{Insufficient time}

Lack of computer, time, and technical support can be faced by teachers because they were motivated in undergoing training in the use of technology. (Nikian, Nor, Aziz. 2013). Moreover, using ICT without careful planning and well-defined objectives will 
more likely be a waste of time and effort. ICT uses in English language teaching and multisensory delivery, in particular, have their limitations as well. Poor pedagogical planning is likely to undermine the use of ICT in the EFL classroom. (Azmi, 2017). This is confirmed by the following excerpt from $T(7)$ :

E11, T(7): I do not know how to use any of the tools. So, I decided to not use it for my teaching. To learn it would need more time, I think. I don't have time; there is a lot of paperwork and also administrative work that I need to do for school, no time to search for new materials from the internet and prepare them for teaching.

Based on the explanation by T7 in E11, extensive paperwork from the school also hinders the teachers' motivation and effort to implement ICT in the classroom. Much of their time at school is about completing paperwork, and this becomes even harder when classes comprise large numbers of students. In Indonesia, it is very typical that a classroom of a public school consists of 40-50 students. Besides, this negative attitude is also one of the factors that hinder technology integration in the classroom for the teachers (Binginlas, 2009)

\section{Lack of effective training}

A study done by Liu, Lin, Zhang, Zheng (2017) stated that to enhance teachers' perception of the usefulness of technology, better facilitate access to technical support, abundant resources, and technology-related pedagogical training. Some studies (dellicarpini, 2012; Levy, 2009; Meskill, Anthony, Hilliker-Vanstrander, Tseng, \& You, 2006) reveal that the challenges faced by both in-service and pre-service ESL teachers in the U.S. regarding their technology integration in ESL classroom include (1) teacher's uncertainty about the effectiveness of instructional technology, (2) inadequate teacher knowledge and skills, (3) lack of technological resources, time, assistance, and (4) policymakers' ignorance of teachers' voices and experiences in making decisions about technology use (Ramola.2013). So, it is a challenge to upgrade teachers in their skills to know the use of technology/ ICT. As T4 and E12:

\section{E12, T(4): I have never attended a workshop or a seminar regarding education technology especially on ICT. I am an autodidact learner on the gadgets that I have. It seems that the school did not put that into their plans for training all the teachers in the school to be able to teach through ICT.}

Some teachers have difficulty using technology/ICT and need to learn more to improve their knowledge and skills. A suggested solution to that the school should send teachers to join conferences to gain new insights when attending a conference. "The main challenges of the teachers were lack of industry exposure and opportunities to develop communication skills; English is a second foreign language where most of the professional students have no good language and the lack of contemporary training facilities (career and language laboratories, e-learning).” (Renuga, M. \& Ezhilan, S., 2016)

7. Lack of accessibility 
Most public schools in Bandung and other parts of Indonesia provide many forms of ICT tools and techniques accessible for use in teaching English and most teachers know how to use ICT tools. Even so, problems exposed by the teachers on its accessibility in schools are as follows:

E13, T(9): In my school, I have all the ICT tools but, we have to take a turn in using it.

So sometimes I have to wait several hours just to access the ICT tools. So, honestly, I am always the last one to access it and I can feel that I have a lack of chance to access the ICT in my school. I wish the school could provide the tools in every room so that we do not wait for one after the other.

8. Lack of technical support as barriers to ICT/ technology

E14, T(1): In my school, we do have computers, projectors but the internet connection is very slow. We do have Wi-Fi but it works very slow because of so many users. So, If I want to browse, I use my hotspot from my smartphone to look for teaching material, or when we do need the internet for teaching like video conferencing with other class from another country or across the nation.

9. Teachers are generally weak

Kolbakova (2014) suggests that using ICT in the teaching and learning process adds more work and additional struggle from teachers to meet the needs of every student in the class. ICT may not be appropriate for all learners in all situations and purposes, and, therefore, it requires considerable learner training to make use of it successfully

E15, T(7): Teachers are generally weak in preparing our lesson through the use of ICT because we are mostly autodidact learners of the ICT tools. So, we do have problems in the planning of the activities through ICT especially for the writing class because we do not have yet the plagiarism checkers.

10. Delivering informal learning

E16, T(8): I think that when we use ICT tools in teaching it to connotate informal teaching. Because we teachers are stuck to the traditional method where the teacher does the teaching. But with the use of ICT tools, the students can just do their class activities on their own. It's a challenge for the teacher to be able to shift from the paradigm of the formal classroom to informal classroom through learning takes place.

\section{CONCLUSION}

Based on the results of the research on English teachers' perceptions and challenges to the implementation of technology/ICT in ELT classrooms, several conclusions can be drawn and it can be concluded that teachers in Bandung have a positive perception of the use of technology to teach in the classroom to help students facilitate their lessons. ICT helps them 
obtain information easily and swiftly, besides that, they also think that ICT makes the class more interesting than discussion and teaching without using any tools. The teachers in this study all agree that technology is very useful as it can assist them in teaching English.

Nevertheless, ICT can never replace teachers because it cannot be the living role model that the teachers can offer the students. The computer cannot comfort the students when they are sad, ICT can never take the place of the teacher in the classroom, but it can assist the teacher to be able to teach efficient and effective.

They tend to feel helped by technology, and they also assume that technology can give them a boost in their knowledge of technology. Although, on the one hand, they also have a struggle or challenge in using technology.

Age, gender, or experience does not prevent them from using technology. However, at different ages they continue to use to make it easier to get information, making teaching and learning more interesting.

The interviews showed that they proposed that:

1. The school should have enough funding and provide sufficient facilities for the teachers to be encouraged to use ICT in their teaching

2. Limited ICT tools and low internet connection at schools are the dominant challenges

3. The teachers have to share the tools with other teacher and this wastes time to wait for their turn to use ICT.

4. The lack of knowledge and training experience that teachers' have.

\section{References}

Alavinia, P., Qoitassi, K. (2013). On the Viability of Vocabulary Learning Enhancement through the Implementation of MALL: The Case of Iranian EFL Learners. Journal of Language and Research, Vol. 4, No. 2, pp. 412-426, March 2013 (C) 2013 Academy

Manufactured in Finland. DOI:10.4304/jltr.4.2.412-426. Retrieved from: http://www.academypublication.com/issues/past/jltr/vol04/02/25.pdf Albirini, A. (2006). Teachers' attitudes toward information and communication technologies: the case of Syrian EFL teachers. Elsevier Computers \& Education 47 (2006) 373-398.

Azmi, N. (2017). The Benefits of Using ICT in the EFL Classroom: From Perceived Utility to Potential Challenges. Journal of Educational and Social Research. Vol 7 no.1 pp. 111-118. DOI: 10.5901/jesr.2017.v7n/p111 Retrieved from: https://content.sciendo.com/abstract/journals/jesr/7/1/article-p111.xml

Tinsley, \& T. J. Van Weert (Eds.), World conference on computers in education VI: WCCE 95 Liberating the Learner (pp. 35-42). London: Chapman \& Hall.

Cavas, B., Cavas, P., Karaoglan, B., \& Kisla, T. (2009). A study on science teachers' attitudes toward Information and Communication Technologies in education. TOJET: The Turkish Online Journal of Educational Technology, 8(2), 20-32.

Carbonilla G., V. \& Bhati, S. S. (2016). Students' perception of the use of technology in the classroom at higher education institutions in the Philippines. Asian Journal of Education and eLearning, 4 (3), 92-103. Retrieved from: https://ro.uow.edu.au/cgi/viewcontent.cgi?referer=\&httpsredir=1\&article=1878\&context=buspa pers 
Chow, P. (2015) Teacher's attitudes towards technology in the classroom 1 teacher's attitudes towards technology in the classroom. A Master of Teaching Department of Curriculum, and Learning Ontario Institute for Studies in Education of the University of Toronto. Retrieved from: https://tspace.library.utoronto.ca/bitstream/1807/68680/1/Chow_Paul_DL_201506_MT_MTRP. pdf

Dellicarpini, M. (2012). Building computer technology skills in TESOL teacher education. Language Learning \& Technology, 16 (2), 14-23, http://dx.doi.org/10125/44280, Retrieved from http://www.lltjournal.org/item/2766

Elsaadani, M. (2012). Teaching staffs' attitudes toward ICT: Is gender a factor? International Women Online Journal of Distance Education, 1(2), 21-30.

Ertmer, P. A., \& Hruskocy, C. (1999). Impacts of university/elementary school partnership designed to support technology integration. Educational Technology Research and Development, 47(1), 81-96.

Gonen, K. (2018). ESL Teachers' Perceptions of Using Technology. Conference: ELI Symposium 2018 at King Abdulaziz University, Jeddah

Granito, M., \& Chernobilsky, E. (2012). The effect of technology on a student's motivation and knowledge retention. Proceedings of Northeastern Educational Research Association Conference (NERA, 2012) (pp. 1-22). Paper 17. Retrieved November 23, 2015 from http://digitalcommons.uconn.edu/nera_2012/17

Haney, J. J., Czerniak, C., \& Lumpe, A. T. (1996). Teachers' beliefs and intentions regarding the implementation of science education reform strands. Journal of Research in Science Teaching, 33, 971-993.

Katemba, C., V. (2019), Students' Vocabulary Enhancement at Grade 10: A Comparative Study Using CALL \& MALL in Indonesia. CALL-EJ, 20(1), 87-114. http://callej.org/journal/20-1/Katemba2019.pdf

Kolbakova, F. (2014). The Use of ICT among the Teachers of English in Estonia by Comparison between Europe and Asia (Master's thesis). University of Tartu, Tartu, Estonia. Retrieved October 9, 2016, Retrieved from http://dspace.ut.ee/bitstream/handle/10062/46990/Master's_Thesis_Kolbakova.pdf Kurniawan,

Levy, M. (2009). Technologies in use for second language learning. The Modern Language Journal, 93. 769-782, https://doi.org/10.1111/j.1540-4781.2009.00972.x, Retrieved from https://onlinelibrary.wiley.com/doi/abs/10.1111/j.1540-4781.2009.00972.x

Liu, H., Lin, C., Zhang, B., Zheng, B. (2017). Chinese Language Teacher's Perceptions of and Instructional Use of Technology: A Path Analysis: University of Exeter UK. Retrieved From https://ore.exeter.ac.uk/repository/bitstream/handle/10871/28117/JECR_Liu_Lin_Zhang_Zheng .pdf? sequence $=2$

Marie- Anne, Kupczynski, L., Kee, R.(2013). Teacher's Perception of Technology Use in the Schools. SAGE Open 2(1) DOI: 10.1177/2158244012440813 Retrieved from: https://journals.sagepub.com/doi/abs/10.1177/2158244012440813

Marcinkiewicz, H. R. (1994). Computers and teachers: Factors influencing computer use in the classroom. Journal of Research on Computing in Education, 26 (2), 220-237.

Meskill, C., Anthony, N., Hilliker-Vanstrander, S., Tseng, C.-H., \& You, J. (2006). CALL: a survey of K-12 teacher uses and preferences. TESOL Quarterly, 40 (2). Pp. 439-451, https://www.jstor.org/stable/40264532, Retrieved from: https://onlinelibrary.wiley.com/doi/abs/10.2307/40264532 
Mollaei \& Riasati, (2013). Teachers' Perception of Using Technology in The Language Classes International Journal of Applied Linguistics and English Literature, Vol 2, No.1. Retrieved from: http://www.journals.aiac.org.au/index.php/IJALEL/article/view/817/749

Muslem, A., \& Abbas, M. (2017). The effectiveness of immersive multimedia learning with peer support on English speaking and reading aloud. International Journal of Instruction, 10(1), 203-218.

Nikian, S., Nor, F. M., Aziz, M. Malaysian Teachers' Perception of Applying Technology in the Classroom. Procedia - Social and Behavioral Sciences 103 ( 2013 ) 621 - 627. Retrieved from: https://core.ac.uk/download/pdf/82290151.pdf

Pelgrum, W.J. (2001). Obstacles to the integration of ICT in education: Results from a worldwide educational assessment. Computers \& Education, 37, 163-178.

Ramorola, M., Z. (2013). Challenge of effective technology integration into teaching and learning. Africa Education Review 10(4) pp. 654 - 670. DOI: 10.1080/18146627.2013.853559 Retrieved from: https://tccl.arcc.albany.edu/knilt/images/c/c3/Challenge_of_effective_Tech.pdf

Rank, T., Warren, C., \& Millum, T. (2011). Teaching English using ICT: A Practical Guide for Secondary School Teachers. London: Continuum.

Renuga, M. \& Ezhilan, S. (2016). Language Teachers of Technology Education: Challenges

Needs and Transformations: Journal of Asian and African Studies, 51(4). Pp. 480-493,

https://doi.org/10.1177/0021909614547603, Retrieved from:

http://journals.sagepub.com/doi/full/10.1177/0021909614547603

Rusanganwa, J. (2013). Developing a multimedia instrument for technical vocabulary learning: a case of EFL undergraduate physics education. Computer Assisted Language Learning DOI: 10.1080/09588221.2013.784708

Tearle, P. (2004) Implementation of ICT in UK secondary schools. Implementation of ICT in secondary schools. Paper presented at the European Conference on Educational Research, University of Crete.

Tengku, M., S. \& Yusus, Y., Q. (2015). Perceptions of using ICT in their teaching: To use or to reject? Teaching English with Technology, 15(4), 29-43, http://www.tewtjournal.org

Veen, W., (1993). The role of beliefs in the use of information technology: implications for teacher education, or teaching the right thing at the right time. Journal of Information Technology for Teacher Education, 2(2), 139-153.

Wadmany, R. (2006). Teacher's belief and Practices in Technology-based Classrooms: A Developmental View. Journal of Research on Technology In Education, 39(2), 157-181.

Yang, S. \& Walker, V. (2015). A Pedagogical Framework for Technology Integration in ESL Classrooms: The Promises and Challenges of Integration: Journal of Educational Multimedia and Hypermedia (2015) 24(2). Pp. 179-203, Retrieved from:

https://www.learntechlib.org/primary/p/147474/ 
